\title{
On the chronology and the phonetics of the change $o>u$ in final closed syllables in Latin
}

\begin{abstract}
It has generally been assumed that the Old Latin vowel weakening $o$ $>u$ in final closed syllables occurred before word-final $m$ and word-final $s$ at the same time. The present article argues that this assumption is incorrect, since the inscriptional evidence clearly shows that the change before $m$ took place later than before $s$. This chronological difference is due to the different phonetic properties of -om [-õ] and -os [-o $\left.\mathrm{o}^{\mathrm{s}}\right]$. It is also suggested that, at least in some cases, the sound change -om >-um could have had analogical support as well.
\end{abstract}

Keywords: Old Latin, inscriptions, vowel weakening, final syllable, nasalization, relative chronology, archaizing

Máté Ittzés: Eötvös Loránd University; ittzes.mate@btk.elte.hu

\section{Introduction}

Vowel weakening or vowel reduction in medial and final syllables is one of the most often treated sound changes in the historical phonology of Latin (for general overviews see, e. g., Leumann 1977: 79-95; Sihler 1995: 59-71; Meiser 1998: 66-74; Weiss 2009: 116-124). One of the processes involved is the change of short $o$ to $u$ in final closed syllables, which is attested before final $d, l, m, r, s$ and the cluster $n t$. This change affects some of the most frequent inflectional endings of Latin, such as the $o$-stem nom. and acc. sing. endings -os, -om > -us, -um; the dat.-abl. plur. ending -bos > -bus of consonant-, $i-, u$ - and $\bar{e}$-stems; the gen. plur. ending -(r)om > -(r)um of all declensions; the active verbal endings 3rd plur. -ont $>$-unt and 1st plur. ${ }^{\star}$-mos $>-$ mus; the passive verbal endings 3rd sing. ${ }^{\star}$-tor $>$-tur, 1 st plur. ${ }^{\star}$-mor $>$-mur, 3rd plur. ${ }^{\star}$-ntor $>$-ntur. Note also the adverbial suffix ${ }^{\star}$-tos $>$-tus (e. g., intus, cf. Gk. ćvTó $)$ ), the pronominal neuter nom.-acc. sing. ending *-od >-ud (e. g., is-tud, cf. Gk. Tó, OIA tád) and some other more isolated instances such as consol $>$ consul. In the present paper, I will concentrate on one detail of this complex, 
namely the weakening of short $o$ to $u$ before final $s(-o s>-u s$ ) and final $m$ (-om > -um), ${ }^{1}$ which are the most frequent and most widely attested environments.

Almost all works dealing with Latin historical phonology either explicitly state or implicitly assume that the Old Latin change of $o$ to $u$ took place before final $m$ and final $s$ at the same time. For instance, Ernout (1953: 28) in his Morphologie historique du latin writes that "le passage de -om à -um s'est produit à la même date que celui de -os à -us”. According to the Handbuch der lateinischen Laut- und Formenlehre by Sommer and Pfister (Sommer \& Pfister 1977: 116; cf. Sommer 1914: 143), “daß -om sich länger gehalten habe als -os ..., wird durch die Inschriften nicht mit Sicherheit bestätigt”. In his recent Outline of the Historical and Comparative Grammar of Latin, Weiss (2009: 221) also argues that "the change -om > -um seems to have followed a pattern exactly parallel to that of -os to - us and also to have taken place at the same time”. Other authors are not explicit on this point, but do not make a distinction between the two changes either. Such an approach can be observed, for instance, in the works of Leumann (1977: 94); Sihler (1995: 66); Meiser (1998: 71) and even in Hartmann's (2005: 214) recent monograph on the Early Latin inscriptions and their dating. On the other hand, Penney (2011: 226) briefly mentions that the change -om >-um occurred "slightly later" than the change -os >-us "to judge from the inscriptional evidence", but does not treat the problem in more detail. ${ }^{2}$

Before turning to the most decisive inscriptional evidence, we may note another interesting argument concerning the absolute chronology of the sound change in question (cf., e. g., Leumann 1977: 442; Wachter 1987: 291; Meiser 1998: 145; Weiss 2009: 221). Our data show that the analogical $u$-stem gen. sing. ending - $\bar{\imath}$ (type senātī) is relatively frequent already in Plautus' comedies (e. g., senātī Cas. 536, Epid. 188; quaestī Aul. 83, Mos. 1107, Per. 66, Poen. 95; sumptī Cas. 425, Trin. 249). Since this innovated ending, which replaced the original ending *-ous $>-\bar{u} s$, was based on the analogy of the $o$-stem inflection, it can be argued that the $o$-stem nominative singular ending must have already been well established as -us at least in Plautus' time (end of 3rd c. B. C.) in order to be able to induce the

1 In my view, the change -om $>-u m$ has to be separated from other instances of $o>u$ before $m$ (such as, e. g., umbilicus < ${ }^{\star}$ ombilīko-, cf. Gk. ỏ $\mu \varphi \alpha \lambda$ ó ; umerus < ${ }^{\star}$ omeso-, cf. Umb. loc. sing. onse, Gk. $\tilde{\omega} \mu o{ }^{\prime}$; see, e. g., Sihler 1995: 43; Meiser 1998: 83; Weiss 2009: 140), which occur in initial syllables and cannot therefore be connected immediately to stress-induced weakenings in non-initial syllables.

2 Another notable exception is Nishimura 2010a: 172-3 with n. 1, who has given a basically correct evaluation of the problem (for details see below). Nishimura's article came to my attention only after the presentation of my paper at the conference The Sound of Indo-European 3 in November 2014. I was glad to realize that I arrived at virtually the same conclusion independently from him. 
proportional analogy which resulted in the creation of the new $u$-stem genitive ending: nom. $-u s(<-o s)$ : gen. $-\bar{\imath}=$ nom. $-u s(<-u s)$ : gen. $\mathrm{X} \rightarrow \mathrm{X}=-\bar{\imath}$. I would add, however, that the proportional analogy might theoretically have started to operate already at the time when there still was a fluctuation between -os and -us in the $o$-stem declension.

\section{The inscriptional evidence}

Let us turn now to the analysis of the inscriptional evidence. It is a matter of fact that the more modern form of both endings, -us and -um, are first attested in inscriptions that date back at least to the 3rd c. B. C. This fact is in accordance with the observation concerning Plautus' $u$-stem genitives and taken together, they indeed seem to justify an approximately 3rd c. B. C. dating of the sound change in terms of absolute chronology.

For -us, the earliest securely dated inscription is the text of the inscribed cuirass from Falerii (241 B. C.; Zimmermann 1986: 40), which has consolibvs. ${ }^{3}$ For - um, the earliest securely dated example is CIL I ${ }^{2} 610$ (200 B. C.) from the city of Rome, which provides itervm. ${ }^{4}$ There exist some pieces of undated inscriptional evidence for both endings which seem to be somewhat older. The epitaph of Scipio Barbatus (CIL I ${ }^{2}$ 6-7; around 260 B. C. ${ }^{5}$ ) already provides five examples of -us (Cornelivs, Lvcivs, Barbatvs, Prognatvs and qvoivs). Perhaps the Fucine Lake inscription ( $\mathrm{CIL} \mathrm{I}^{2}$ ) can be taken into account as well, which was probably written in the late 4 th c. B. C. and which records the ablative plural L[ECIO]NiBvs. ${ }^{6}$ For the ending $-u m$, we might consider a dedicatory inscription

3 This inscription is considerably older than CIL I ${ }^{2} 608$ and 609 (both from 211 B. C.), which are the first securely dated examples of the modern form -us (CLAvDivs) from the city of Rome (Wachter 1987: 285; Clackson \& Horrocks 2007: 131). The Latin inscriptions on the recently discovered rostra from Egadi (cf. Prag 2014), which can probably be dated to the period shortly before 241 B. C., have no instances of the modern ending - $u$ s but only examples of - $o(s)$. The existence of the ending $-o(m)$ is not assured on the Egadi inscriptions, since viroeñ in line 3 of Egadi 1 is not necessarily to be segmented as VIRo(м) EṆ[ with VIRo(м) as genitive plural (see the argumentation of Prag 2014: 45-47). I owe the reference to the Egadi inscriptions and Prag 2014 to my anonymous reviewer.

4 Wachter 1987: 285; Clackson \& Horrocks 2007: 131; Nishimura 2010a: 172.

5 On the dating of the inscription see the detailed argumentation of Wachter 1987: 301-342; cf. Adamik 2009: 155-156.

6 On reading and dating see most recently Clackson \& Horrocks 2007: 112 (following an unpublished 2006 paper by M. Crawford); cf. also Wachter 1987: 370-372; Nishimura 2010a: 171 ("ca. 350-300"). The inscription exhibits some apparently non-Latin ("Marsian”) features, but the 
from Falerii (CIL I ${ }^{2}$ 364), which is dated by some scholars to the second half of the 3rd century B. C. ${ }^{7}$ and which has DonvM, GONLEGIVM, ACIPTVM and OPIPARVM.

However, the interval between the absolute dates of the first attestations (end of 4 th c. B. C. for -us [CIL I ${ }^{2}$ 5] vs. second half of 3rd c. B. C. for -um [CIL I ${ }^{2} 364$ ?]) cannot, in my view, be used in itself as immediate evidence for a later change before final $m$. Apart from general problems such as the factor of chance in the attestations, ${ }^{8}$ the dating of not securely datable inscriptions and the potentially different dialectal background of the relevant texts, it is not entirely obvious either how we are to interpret exactly the first occurrence of the outcome of a particular sound change in a given document. Following a diffusionist approach, I assume that the first piece of written evidence for a change, even in an official inscription, cannot automatically be taken to indicate that the change in question already spread to the whole speech community and even less that the change had already finished operating at the time of the particular document and thus contemporary inscriptions should normally not exhibit the older form either. What the first attestation certainly proves, however, is that the change was at least an ongoing process at that time. ${ }^{9}$ This is, of course, not to deny the existence of archaisms, pseudo-ar-

ending -bus itself is genuine Latin. Note incidentally that, for the sake of simplicity, the dialectal affiliaton of the Latin inscriptions is not taken into account in this paper (e. g., CIL I ${ }^{2}$ 60, 61 and 62 come from Praeneste; CIL I ${ }^{2} 366$ from Spoletium [Umbria]; CIL I ${ }^{2} 376$ from Pisaurum [Picenum]), although it is completely possible that different regions underwent the change at slightly different times. For instance, the very early attestation of -bus in CIL I ${ }^{2} 5$ may indicate that the Latin dialect behind the Fucine Lake inscription underwent the change considerably earlier than the Latin dialect of Rome. Note, however, the remarks of Wachter (1987: 487, 489) on the "Gemeinsamkeit der Entwicklung im ganzen Gebiet”, i. e. the city of Rome and its vicinity.

7 Hartmann 2005: 214 with refs. However, according to Wachter 1987: 447, some features of the inscription "scheinen ... eine Datierung vor 150v. kaum zu erlauben" (for a late dating [c. 125 B. C.] see also Warmington 1940: 124-125 with n. 1).

8 Cf. Wachter 1987: 358: "Es fällt hier übrigens auf, dass für -om die moderne Form mit -u- erst später auftritt als bei -os. Es ist kaum möglich schlüssig zu entscheiden, ob dies einer lautlichen Realität entspricht oder bloss auf mehr oder weniger archaisierenden Schreibungen beruht und demnach Zufall ist." The number of the attestations of the two modern endings - $u$ s and - $u m$ cannot be significant either, particularly because -us might well be overrepresented due to the frequent occurrence of $o$-stem personal names in the inscriptions in the nominative singular.

9 See, e. g., Nishimura's (2010a: 171) evaluation of L[ECIO]NIBvs CIL I² 5: "vowel reduction was already an on-going process in as early as the fourth century B. C. E." Cf. also Wachter 1987: 358: "Wenn ferner in einem solchen Dokument neben den modernen auch eher altertümliche Merkmale vorkommen, so wird man davon ausgehen dürfen, dass die zu diesen gehörenden sprachlichen Veränderungen zur Zeit seiner Entstehung noch nicht oder mindestens noch nicht lange vorbei waren." 
chaisms and archaizing in Old Latin inscriptions. ${ }^{10}$ However, the assumption that all, even the earliest, attestations of old forms following the first occurrence of the more modern form should automatically be regarded as artificial archaisms is in my view far-fetched.

Having all this in mind, I propose to follow a cautious approach and attempt to determine the relative chronology of the two changes (-os >-us vs. -om >-um) on the basis of such inscriptions that exhibit old and new endings simultaneously, assuming that in the "idiolects" of the individual inscriptions potential archaizing may be expected to affect both endings in more or less the same measure ${ }^{11}$ and thus the distribution of the endings may indeed reveal the relative chronology of the two processes.

The analysis of the Old Latin inscriptions of the late 4th - early 2nd centuries B. C. ${ }^{12}$ reveals that there are several documents that preserve the old form -om along the modern ending -us (sometimes preserving instances of old -os as well), but there are only two short inscriptions in which their distribution is the opposite, i. e. which have the modern ending -um beside the old -os. ${ }^{13}$ The relevant data are summarized in Table 1 (p. 334) and Table 2 (p. 335).

10 On this phenomenon see, in particular, Wachter 1987: 283-286, 310 (and passim); Clackson \& Horrocks 2007: 131-132.

11 Cf. Wachter 1987: 286: "Prinzipiell darf aber schon eine Inschrift, die éinen sicheren Archaismus aufweist, grundsätzlich verdächtigt werden, noch andere altertümliche Züge in archaisierender Weise zu verwenden.”

12 Concerning the dating of the inscriptions, I consulted CIL; Warmington 1940; Ernout 1957; Wachter 1987; Hartmann 2005 and Clackson \& Horrocks 2007. Except for securely dated inscriptions, the dates given in the last column of the tables are mostly rough approximations. CIL I ${ }^{2} 25$ (the honorary inscription of Duilius from the Columna Rostrata) has been left out of consideration in accordance with Wachter 1987: 359-361 and Clackson \& Horrocks 2007: 108-111.

13 We have to exclude those cases from our discussion in which the old ending -os or -om is preceded by the grapheme $\langle v\rangle$, phonetically [u] or [u] . As is well known, the old forms $\langle-v o s\rangle$ and 〈-voм〉 survived until late republican times (e. g., CIL I ${ }^{2} 584$ [117 B. C.]: RIvom, compascvos; CIL I ${ }^{2}$ 588 [78 B. C.]: AEQVOM; CIL I 594 [47-44 B. C.]: TRIDVOM, QVADRIDVOM, MORTVOM; among earlier inscriptions note, e. g., CIL I² 360 [before 200 B. C.]: Rvtilivs, but Diovos; CIL I² 1617 [after 200 B. C.]: SACRVM $[2 \times]$, but servos). The reason for the retention of the old forms was probably not merely orthographic (i. e. avoidance of the grapheme sequence $\langle v v\rangle$ ), but rather phonetic: the old $o$ was preserved dissimilatorily to avoid the uncomfortable sound sequence [uu] or [ưu] (Leumann 1977: 49; Meiser 1998: 84; Weiss 2009: 220-221). 
Table 1. Examples of the distribution "modern -us alongside old -om"14

\begin{tabular}{|c|c|c|c|}
\hline CIL I² No. & modern -us or -um & old -os or -om & date (B. C.) \\
\hline 5 & $\mathrm{~L}[$ ECIO $]$ NIBVS & $\begin{array}{l}\text { CAso(s) } \\
\text { CANTOVIo(s) } \\
\text { AprvfClano(s) } \\
\text { CALICOM } \\
\text { DONOM }\end{array}$ & end of 4 th century \\
\hline $6-7$ & $\begin{array}{l}\text { CoRNELIVS } \\
\text { LvCIVS } \\
\text { BARBATVS } \\
\text { PROGNATVS } \\
\text { QVOIVS }\end{array}$ & $\begin{array}{l}\text { [CoRneli]o(s) } \\
\text { SAMNIO(m) }\end{array}$ & c. 260 \\
\hline $8-9$ & Tempestatebvs & $\begin{array}{l}\text { CORNELIO(s) } \\
\text { OINO(M) } \\
\text { DVONORO(M) } \\
\text { OPTVMO(M) } \\
\text { VIRO(M) } \\
\text { LVCIOM } \\
\text { FILIOS }\end{array}$ & c. 230 \\
\hline 26 & Albanivs & DONO[M] & before 200 \\
\hline 27 & Brvttivs & DONO(M) & before 200 \\
\hline 32 & [...]onivs & DONOM & before 200 \\
\hline 60 & NATIONV(s) & DONOM & first half of 3 rd century \\
\hline 62 & $\begin{array}{l}\text { LEIGIBVS } \\
\text { SALuTVS }\end{array}$ & $\begin{array}{l}\text { Gemenio(s) } \\
\text { Dono(m) }\end{array}$ & middle of 3rd century \\
\hline 392 & A[T]IEDIV[s] & DONO(M) & before 200 \\
\hline 976 & Terentivs & DONOM & not much later than 200 \\
\hline 1920 & Pescennivs & DONO(M) & 2nd century \\
\hline 2661 & CARPNiv(s) & $\begin{array}{l}\text { Remo(s) } \\
\text { Titv[LE]No(s) } \\
\text { FACIEdo(M) }\end{array}$ & 171 \\
\hline 2868 & Calpvrnivs & $\operatorname{DONO}(\mathrm{M})^{15}$ & $\begin{array}{l}\text { second half of } 3 \text { rd } \\
\text { century }\end{array}$ \\
\hline 2874 & $\begin{array}{l}\text { Ceseivs } \\
{[\ldots] \text { Isivs }}\end{array}$ & $\operatorname{SEINO}(M)^{16}$ & first half of 3 rd century \\
\hline no CIL-No. & CONSOLIBVS & САРТО(М) & $241^{17}$ \\
\hline
\end{tabular}


Table 2. Examples of the distribution "modern -um alongside old -os"18

\begin{tabular}{llll}
\hline CIL I $^{2}$ No. & modern -us or -um & old -os or -om & date (B. C.) \\
\hline 33 & DONVM & Terebonio(s) $)^{19}$ & before 200 \\
61 & DONV(M) & Cestio(s) $)^{20}$ & before 200 \\
\hline
\end{tabular}

It is, of course, likely that in a few (some scholars would perhaps say most or even all) inscriptions of the 3rd and 2nd centuries, the old forms -os or -om are indeed spelling archaisms after the completion of the sound change. However, the fact that the old spelling in the case of -om survived longer than the spelling -os is in my view still significant, since it can be regarded as a reflection of the fact that the change itself occurred later. If the two changes had really taken place at the same time as variants of the same diachronic process, we should find, according to statistical probability, approximately the same number of inscriptions with the opposite distribution (old -os along modern -um), but this is quite clearly not the case. The observed distribution of the endings is even more remarkable if we con-

14 The notation [...] is used for editorial restorations, while (...) indicates letters not written in the inscription. Apart from the inscriptions included in the table, note also CIL I ${ }^{2} 12$ (c. 160 B. C.), which has Gnatvs (and mortvos) next to Antioco(м). However, the latter form may merely imitate Greek Avtíoxov (cf. CIL I ${ }^{2}$ ad loc.) and is thus irrelevant to the present discussion.

15 Wachter (1987: 441) remarks that Dono might also be a dative.

16 Cf. Wachter 1987: 408 (and the previous footnote) on the possibility of seINo being dative or ablative.

17 Not yet included in CIL I²; published in Zimmermann 1986: 40.

18 In CIL I² 672 (112-111 B. C.), Warmington (1940: 102) reads "Minatio(s)" beside "mercatorum". However, the reading $\langle$ Minatio[〉 is incorrect and should be replaced by $\langle$ Minatic [ $\rangle$, which may be segmented and interpreted as Minati(vs) C[ (cf. CIL I² fasc. 4: 931).

19 Note that $\langle$ Terebonio $\rangle$ is written exactly under dat. (!) $\left\langle[\mathrm{Nv}]_{\text {Misio }}\right\rangle$ (see the transcription in $\mathrm{CIL} \mathrm{I}^{2}$ ad loc.). Was its orthography perhaps influenced by the latter form?

20 〈Cеsтio) is in all probability a singular form in -os (cf., e. g., Leumann 1977: 404; Wachter 1987: 232; Bakkum 2009: 292) and not a (dialectal) plural in -ōs or a dual in -ō as interpreted by some earlier scholars (such as, e. g., Ernout 1957: 23 [plural]; CIL I² ad loc. [plural or dual]). According to Wachter 1987: 237 (see also 257), it is possible that the ending $-u(m)$ in Donv(M) vs. $-o(n t)$ in DEDERo (CIL I ${ }^{2}$ 61) is due to a "kontrastive Schreibung", since "nach dem $o$ des ersten Wortes der Vokal der Endung als geschlossener empfunden wurde als nach den beiden $e$ des zweiten", which may perhaps mean that the vowel of the second syllable in Donv(м) had not yet been fully raised to [ũ] but was still something between [ũ] and [õ] (on the phonetics of -om/-um see below). On the orthographic vacillation in general see also Kümmel 2007: 91-92. 
sider the fact that the words ending in -os/-us are very frequently proper names, which cross-linguistically tend to be more conservative in their orthography. ${ }^{21}$

These circumstances indicate that the change-om >-um did indeed take place later than the change -os >-us, even if we cannot determine precisely either their absolute date or the interval between them.

\section{The phonetic background}

How can we explain this probably not very large, but still clearly palpable chronological difference between the two changes? The clue lies in the precise phonetic value of word-final -om/-um. ${ }^{22}$ As is well known, by the time of the earliest Old Latin inscriptions (beginning at the end of the 4th century B. C.), the pronunciation of the word-final labial nasal had been reduced: it was not pronounced as a full consonant $[\mathrm{m}]$ anymore, but was rather realized as the nasalization of the preceding vowel (cf., e. g., Allen 1978: 30-31; Sommer \& Pfister 1977: 219-221; Leumann 1977: 223-226; Weiss 2009: 62, 133 n. 50), which means that, for instance, -om was pronounced probably as [-õ]. ${ }^{23}$

The reduced pronunciation is reflected by the fact that final $m$ is frequently omitted in writing in Old Latin inscriptions. Although the orthographic practice gradually changed in the course of the 2 nd c. B. C. and the official spelling established, or rather reestablished, the writing of final $m$, its pronunciation must have remained the same, which is indicated, first of all, by the well known metrical feature that the sequence of vowel plus final $m$ is subject to elision or synaloepha ${ }^{24}$

21 Cf., e. g., Wachter 1987: 489: “in Eigennamen bleibt wegen ihrer Häufigkeit die Schreibung mit $o$ noch lange in Gebrauch" (see also Wachter 1987: 310).

22 Cf. already Nishimura 2010a: 173 with n. 1.

23 Although the distribution of nasalized vowels was very restricted, since they occurred only in word-final position (and possibly before the sequence of nasal plus continuant, i. e. before the consonant clusters [ns] and [nf]), they probably have to be regarded as separate entities among the vowel phonemes of Latin: Class. Lat. /ã/, /ẽ/, /ĩ/, /ũ/ (there was no /õ/ in Class. Lat. any more). On the question of their phonemic status see, e. g., Cser 1999: 174; Clackson 2008: 77; McCullagh 2011: 87, 89. It has been argued that the nasalized vowels were also inherently long (e. g., Allen 1978: 30; Cser 1999: 174) but there is some evidence which contradicts this assumption (see, e. g., Weiss 2009: 133 with n. 50,134). See, however, below on the phonetic length of nasal vowels (cf. also Allen 1978: 119 on its non-distinctive character).

24 On the question of the precise way(s) of avoiding hiatus in such cases see Allen 1978: 78-82; Weiss 2009: 132-136 (also on cases in which final $m$ seems to have been not fully reduced: e. g., in stressed monosyllables). 
before an initial vowel almost without exception in Old as well as Classical Latin verse (e. g., Leumann 1977: 223-224).

Thus, we are facing actually two processes that are orthographically, on the level of graphemes, similar, but phonetically quite different: 1 . the change of the short oral vowel [o] to [u] before a final [s] (which consonant was pronounced quite weakly in Old Latin: cf., e.g., Leumann 1977: 227-228; Allen 1978: 36-37) and 2. the change of the word-final nasalized vowel [õ] to [ũu: i. e. $\left[-o^{\mathrm{s} \#]}>\left[-\mathrm{u}^{\mathrm{s} \#}\right]\right.$ vs. [-õ\#] $>[-\tilde{u} \#] .{ }^{25}$

\section{The synchronic and diachronic typology of nasalization}

Let us now have a closer look at the articulation of nasal vowels in general and the synchronic and diachronic typology of nasality and nasalization. First of all, it has been argued (see the references in Hajek \& Maeda 2000: 52) that the devel-

25 My anonymous reviewer remarks that the change -om >-um should not be separated from the change -ont >-unt, for which nasalization seems indicated by Old Latin spellings in -ot. However, it has to be noted at the outset that the omission of the nasal $n$ in -ont $>-$ unt is much less common in the inscriptions than the omission of $m$ in -om >-um. There seem to be only two instances in which the nasal is omitted but the dental written (DEDRot CIL $\mathrm{I}^{2} 378$, Pisaurum, 3rd-2nd c. B. C.; EMERvt CIL I I 1513, Cora, 3rd-2nd c. B. C.) and six or seven more in which both letters are missing (e. g., DEDERo CIL I ${ }^{2}$ 2659, Lacus Albanus, 3rd c. B. C.; DEDRo CIL I ${ }^{2}$ 379, Pisaurum, 3rd-2nd c. B. C.; see Kümmel 2007: 100 for the attestations in perfect forms). The rarity of the omission of $n$ suggests that the potential nasalization in -ont (i.e. [-õt]) was not as widespread as it was in the case of -om [-õ] and can perhaps be regarded only as a dialectal feature. One could also imagine that $n$ in -ont remained an independent segment and the nasalization was only a non-distinctive phonetic feature of the preceding vowel (i. e. [-õnt]). On the other hand, it can be clearly seen that the vowel before final $n t$ follows the trends we observed before final $m$. Three inscriptions from Table 1 also have -ont or -o(nt): Cosentiont CIL $\mathrm{I}^{2} 8-9$; [...]Ront and FECRONT CIL I ${ }^{2} 2874$ (cf. Wachter 1987: 408); ATOLERo CIL I ${ }^{2} 5$ (cf. Kümmel 2007: 100; but Clackson \& Horrocks (2007: 113) following M. Crawford read ATOLERE). It is remarkable that CIL I ${ }^{2} 61$ from Table 2 has DEDERo (on the difference between DONv(м) and DEDERo cf. $n$. 20). Warmington (1940: 156-157) interprets (VEDo...) in line 1 of CIL I ${ }^{2} 400$ as “Vedus". The pair VEDo(s) and LocAVERUNT would be an example of the distribution of Table 2 . However, in view of the fragmentary nature of line 1, it is probable that the ending of the name is missing, which may of course have been -us. Similar observations apply to CIL I ${ }^{2} 2661$ from Table 1 , which has CoRAve[...] $\mid$ NT. This is usually restored as CORAVE[Rv] | NT, but might have been rather CORAVE[Ro] | NT. CIL I ${ }^{2} 672$ has CoERavervnt beside alleged (Warmington 1940: 102-103) Minatio(s), but see $n .18$ above on the correct reading of the proper name. 
opment of distinctive nasalization occurs preferentially in the context of low vowels before spreading gradually to mid and finally to high vowels ("vowel height parameter"). This phenomenon has often been connected (see the references in Hajek \& Maeda 2000: 57) to the fact that during the pronunciation of nasal vowels, the velum (soft palate) is lowered to allow the air to pass through the nasal cavity as well as the mouth ("velic opening hypothesis"). This articulatory feature, the lowering of the velum, has been regarded as being not easily compatible with the articulation of such vowels in which the tongue is positioned high in the mouth (especially in the case of back [or "velar"] vowels). ${ }^{26}$ An important piece of evidence for this theory has been the case of nasal vowels in the phonological history of French. On the basis of the distribution of assonance in Old French poetry, it has been assumed that there was a gradual spread of nasalization starting with the low vowel [a] $>$ [ã] around the turn of the first millennium and finishing with the high vowel [y] > [ỹ] some centuries later (e. g., Pope 1952: 167-182; Herman 1967: 64-65, 68-69, 72, 77, 79, 219; Ruhlen 1978: 224).

However, recent scholarship (e. g., Hajek \& Maeda 2000 with references) has shown that the situation is more complex and distinctive nasalization does not universally develop preferentially in the context of low vowels. While there are indeed some languages in which low vowels are preferentially nasalized, there also exist others in which the opposite is true. The so-called velic opening hypothesis alone cannot account for the data either. Moreover, even the evidence of Old French has been challenged and found by some scholars to be unreliable. More recent investigations (e. g., Hajek 1993 with refs.) have pointed out that the statistical analysis of the distribution of assonance in Old French poetry does not really support the hypothesis of the gradual spread of nasalization from low vowels to mid and then to high vowels, but a more or less simultaneous process of nasalization irrespective of vowel height.

On the other hand, a typological observation reveals that high and mid nasal vowels tend to be articulated phonetically lower than their oral equivalents, whereas low nasal vowels tend to be higher than their oral partners, which means that nasal vowels are regularly more centralized than their oral equivalents (Ruhlen 1978: 222; cf. also Ohala 1993: 243 and 269 n. 3; Nishimura 2010a: 173 n. 1). ${ }^{27}$ A similar observation has pointed out that when nasalization affects

26 Cf. Pope 1952: 168: "low vowels nasalise more readily than high ones because it is not quite easy to combine the lowering of the soft palate that is required to open the nose passage with the raising of the back or front of the tongue" (see also Herman 1967: 65).

27 As Götz Keydana pointed out to me, this observation is valid also from the point of view of acoustic perception. Cf., e. g., Beddor, Krakow \& Goldstein 1986; Ohala 1993: 243. 
high vowels, they are generally lowered and when low vowels are affected, they are generally raised: "mid vowels ... do not reveal a uniform raising or lowering tendency, but when variables other than vowel height are taken into account (i. e. vowel context and vowel backness) if they are affected by nasalization they are in general lowered” (Quicoli 1990: 325 with reference to Beddor 1982; cf. Pope 1952: 168). Brazilian Portuguese, for instance, has a synchronic phonological rule that raises low vowels to mid vowels when they are nasalized but does not target mid and high vowels (Quicoli 1990: 323-325).

Moreover, the historical phonology of French provides clear diachronic evidence for the lowering of already nasalized vowels (cf., e. g., Pope 1952; Herman 1967). In fact, most nasalized vowels have lowered in the course of time and as a

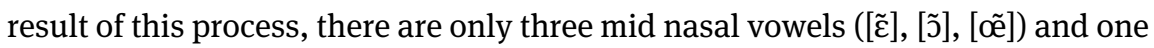
low nasal vowel ([ã]) in Modern French but no high ones. The originally high nasal


ing examples, in which the traditional orthography reflects the earlier pronunciation with higher vowel: temps [tã]; prendre [рьã:dь] (vs. prennent [рьєn]); humble

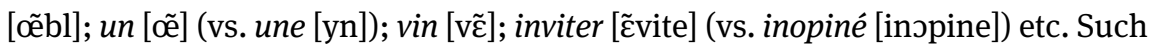
lowerings of high nasal vowels can be observed in various other languages as well. ${ }^{28}$

Another important point is that "nasalized vowels are phonetically longer than their oral counterparts all things being equal” (Barnes 2006: 38; cf. also Whalen \& Beddor 1989; Hajek \& Maeda 2000: 65-66; Nishimura 2010a: 173 n. 1).

We can see that even if some claims made by earlier authors concerning nasalization cannot be substantiated in the light of recent investigations, some generalizations may still be regarded as valid. One such generalization is that nasal vowels tend to be articulated more centralized than their oral equivalents and mid nasal vowels (and naturally high vowels as well) follow lowering rather than raising processes in both synchronic phonological rules and diachronic changes. On the other hand, nasalized vowels tend to be phonetically longer than their oral counterparts.

28 Among the Indo-European languages note, for instance, the lowering of the nasal vowel *[ĩ] to *[ẽ] in Common Slavic (e. g., Fortson 2010: 423; Meillet 1934: 62): e. g., Pre-Slavic *desim-ti'decad' > OCS desętĭ, Polish dziesięć ‘ten' (vs. Lith. dešimtìs). 


\section{Conclusion}

Since the vowel reduction in Latin generally induced the raising of the vowels affected (cf. the analysis of Nishimura 2010b) and targeted short vowels in principle, it is not surprising that the mid back nasal vowel [õ], which was also phonetically longer, underwent the raising to the high back nasal vowel [ũ] later than the corresponding short oral vowel [o] that was raised to [u] (cf. Nishimura 2010a: 173 with n. 1, who regards phonetic length as the main factor).

Having in mind the typological rareness of the raising of mid nasal vowels and the fact that short vowels were targeted by Latin vowel reduction in the first place, it might be suggested that the change [õ] $>[\tilde{u}]$ in final syllables was an analogical process rather than a phonological one. ${ }^{29}$

For instance, one could imagine that in the particularly frequent masculine $o$-stem inflection, the accusative ending [-õ] was transformed into [- $\tilde{u}]$ on the basis of the new nominative ending $\left[-\mathrm{u}^{\mathrm{s}}\right]$ with the raised oral vowel $\left(<\left[-\mathrm{o}^{\mathrm{s}}\right]\right)$ and later, [-ũ] could spread analogically to the nominative-accusative singular of $o$-stem neuters as well. However, there appear to be some difficulties that indicate that analogy alone cannot explain the available data. ${ }^{30}$ There are, namely, a number of other instances of -om becoming -um for which analogical models seem to be lacking (e.g., paradigmatically isolated conjunctions and adverbs such as dum, tum, demum, sorsum; genitive plurals in -(r)um).

One might also argue that the other non-high nasal vowels, [-ã] and [-ẽ] ${ }^{31}$ remained unchanged word-finally due to the absence of analogical motivation (cf., e. g., acc. sing. terram [terrã], not terrem [terrẽ], beside nom. sing. terra [terra]). However, there are other stem classes in which the presence or absence of analogical support apparently did not play a role (e.g., 3rd declension nouns with nom. -is, acc. -em did not replace the latter ending by -im).

It is therefore likely that the change [õ] $>$ [ũ] in final syllables was a regular sound change after all, which was part of the phenomenon called vowel weakening or vowel reduction. However, I do not exclude the possibility that in some

29 Nishimura (2010a: 173 n. 1) argues for the second possibility: "the change -om >-um in final position can also be defined as vowel reduction, despite its relatively late occurrence.”

30 These difficulties have been pointed out by the anonymous reviewer of my article.

31 Traditionally: $a$ and $e$ before final $m$. Notice that some handbooks assert that $a$ became $e$ before a final nasal in general (e. g., Sihler 1995: 65; Meiser 1998: 71). This view seems to be incorrect, however, since there are no examples before $m$, only before $n$ (e. g., tïbicen $<{ }^{*}-k a n$ ). The different treatments are understandable if we take into account that - am and -an were distinct phonetically ([-ã] vs. [-an]). 
cases, in particular the $o$-stem declension, the process had additional analogical backing.

Acknowledgement: The writing of this paper and my participation at the conference The Sound of Indo-European 3 held in Opava, 12-14 November 2014 was made possible by the financial support of the Hungarian Scientific Research Fund (OTKA, project no. PD 100700). I would like to express my thanks for various kinds of help to Nicholas Zair, Götz Keydana, João Veloso, Kanehiro Nishimura, Sándor Kiss and Béla Adamik and to my anonymous reviewer for helpful comments and suggestions. All remaining shortcomings are entirely mine.

\section{Bibliography}

Adamik, Béla (2009). A latin nyelv története. Az indoeurópai alapnyelvtöl a klasszikus latinig. [The History of the Latin Language. From Proto-Indo-European to Classical Latin]. Budapest: Argumentum.

Allen, W. Sidney (1978). Vox Latina. A Guide to the Pronunciation of Classical Latin. 2nd ed. Cambridge: Cambridge University Press.

Bakkum, Gabriël C. L. M. (2009). The Latin Dialect of the Ager Faliscus. 150 Years of Scholarship. Amsterdam: Amsterdam University Press.

Barnes, Jonathan (2006). Strength and Weakness at the Interface. Positional Neutralization in Phonetics and Phonology. Berlin \& New York: Mouton de Gruyter.

Beddor, Patrice S. (1982). Phonological and Phonetic Effects of Nasalization on Vowel Height. PhD thesis. Minneapolis: University of Minnesota.

Beddor, Patrice S., Rena Arens Krakow \& Louis M. Goldstein (1986). "Perceptual constraints and phonological change. A study of nasal vowel height”. In: Phonology Yearbook 3, 197-217.

Clackson, James (2008). “Latin”. In: The Ancient Languages of Asia Minor. Ed. by Roger D. Woodard. Cambridge \& New York: Cambridge University Press, 73-95.

Clackson, James \& Geoffrey Horrocks (2007). The Blackwell History of the Latin Language. Malden \& Oxford: Blackwell.

Cser, András (1999). “Diphthongs in the syllable structure of Latin”. In: Glotta 75, 172-193.

Ernout, Alfred (1953). Morphologie historique du latin. 3rd ed. Paris: Klincksieck.

Ernout, Alfred (1957). Recueil de textes latins archaïques. Nouvelle édition. Paris: Klincksieck.

Fortson, Benjamin W. IV (2010). Indo-European Language and Culture. An Introduction. 2nd ed. Chichester \& Malden: Wiley-Blackwell.

Hajek, John (1993). “Old French nasalization and universals of sound change”. In: Journal of French Language Studies 3, 145-164.

Hajek, John \& Shinji Maeda (2000). "Investigating universals of sound change: The effect of vowel height and duration on the development of distinctive nasalization". In: Papers in Laboratory Phonology V. Acquisition and the Lexicon. Ed. by Michael B. Broe \& Janet B. Pierrehumbert. Cambridge: Cambridge University Press, 52-69.

Hartmann, Markus (2005). Die frühlateinischen Inschriften und ihre Datierung. Eine linguistischarchäologisch-paläographische Untersuchung. Bremen: Hempen. 
Herman, József (1967). Précis d'histoire de la langue française. Budapest: Tankönyvkiadó.

Kümmel, Martin J. (2007). "The third person endings of the Old Latin perfect and the fate of final - $d$

in Latin". In: Proceedings of the 18th Annual UCLA Indo-European Conference. Ed. by Karlene Jones-Bley et al. Washington: Institute for the Study of Man, 89-100.

Leumann, Manu (1977). Lateinische Grammatik. Laut- und Formenlehre. München: Beck.

McCullagh, Matthew (2011). "The sounds of Latin. Phonology". In: A Companion to the Latin

Language. Ed. by James Clackson. Malden \& Chichester: Wiley-Blackwell, 83-91.

Meillet, Antoine (1934). Le slave commun. 2nd ed. Paris: Champion.

Meiser, Gerhard (1998). Historische Laut- und Formenlehre der lateinischen Sprache. Darmstadt:

Wissenschaftliche Buchgesellschaft.

Nishimura, Kanehiro (2010a). “Chronology between word-internal and word-final vowel reduction in Latin”. In: Incontri Linguistici 33, 167-177.

Nishimura, Kanehiro (2010b). "Patterns of vowel reduction in Latin. Phonetics and phonology". In: Historische Sprachforschung 123, 217-257.

Ohala, John J. (1993). "The phonetics of sound change". In: Historical Linguistics. Problems and Perspectives. Ed. by Charles Jones. London \& New York: Longman, 237-278.

Penney, John (2011). “Archaic and Old Latin”. In: A Companion to the Latin Language. Ed. by James Clackson. Malden \& Chichester: Wiley-Blackwell, 220-235.

Pope, Mildred K. (1952). From Latin to Modern French with Especial Consideration of Anglo-Norman. Manchester: University of Manchester Press.

Prag, Jonathan R. W. (2014). "Bronze rostra from the Egadi Islands off NW Sicily. The Latin inscriptions”. In: Journal of Roman Archaeology 27, 33-59.

Quicoli, A. Carlos (1990). “Harmony, lowering and nasalization in Brazilian Portuguese”. In: Lingua 80, 295-331.

Ruhlen, Merritt (1978). “Nasal vowels”. In: Universals of Human Language. Vol. 2: Phonology. Ed. by Joseph H. Greenberg. Stanford: University Press, 203-241.

Sihler, Andrew L. (1995). New Comparative Grammar of Greek and Latin. New York \& Oxford: Oxford University Press.

Sommer, Ferdinand (1914). Handbuch der lateinischen Laut- und Formenlehre. 3rd ed. Heidelberg: Winter.

Sommer, Ferdinand \& Raimund Pfister (1977). Handbuch der lateinischen Laut- und Formenlehre. Vol. 1: Einleitung und Lautlehre. 4th ed. Heidelberg: Winter.

Wachter, Rudolf (1987). Altlateinische Inschriften. Sprachliche und epigraphische Untersuchungen zu den Dokumenten bis etwa 150 v. Chr. Bern, Frankfurt, New York \& Paris: Lang.

Warmington, Eric H. (1940). Remains of Old Latin. Vol. 4: Archaic Inscriptions. Cambridge \& London: Harvard University Press.

Weiss, Michael L. (2009). Outline of the Historical and Comparative Grammar of Latin. Ann Arbor: Beech Stave.

Whalen, Douglas H. \& Patrice S. Beddor (1989). “Connections between nasality and vowel duration and height. Elucidation of the Eastern Algonquinian intrusive nasal”. In: Language 65, 457486.

Zimmermann, Jean-Louis (1986). “La fin de Falerii Veteres. Un témoignage archéologique”. In: The J. Paul Getty Museum Journal 14, 37-42. 